\title{
Effect of different levels of fibrolytic enzyme on feed digestibility and production performance in lactating dairy cows
}

\author{
Hazrat Salman Sidique ${ }^{1}$, Muhammad Tahir Khan ${ }^{1}$, Haq Aman Ullah ${ }^{2 *}$, \\ Muhammad Mobashar ${ }^{1}$, Muhammad Ishtiaq ${ }^{3}$ and Sohail Mehmood ${ }^{1}$ \\ 1. Department of Animal Nutrition, The University of Agriculture Peshawar, Khyber Pakhtunkhwa-Pakistan \\ 2. Department of Animal Health, The University of Agriculture Peshawar, Khyber Pakhtunkhwa-Pakistan \\ 3. Livestock and Dairy Development Department, Khyber Pakhtunkhwa-Pakistan \\ *Corresponding author's email: drhaqamanullah@aup.edu.pk
}

Citation

Hazrat Salman Sidique, Muhammad Tahir Khan, Haq Aman Ullah, Muhammad Mobashar, Muhammad Ishtiaq and Sohail Mehmood. Effect of different levels of fibrolytic enzyme on feed digestibility and production performance in lactating dairy cows. Pure and Applied Biology. Vol. 9, Issue 1, pp918-924. http://dx.doi.org/10.19045/bspab.2020.90096

Received: 28/08/2019 Revised: 17/12/2019

Accepted: 20/12/2019

Online First: 02/01/2020

\section{Abstract}

The poor quality conventional feed for the livestock production in Pakistan are wheat straw, tops of sugar cane and tree leaves. To enhance the nutritive value of feed, this study focused on investigating the effects of fibrolytic enzyme (Fibrozyme ${ }^{\circledR}$, Alltech Inc. Company, USA) at different levels i.e. 0, 5, 10, and 15g/kg of total mix ration on feed intake, digestibility, milk yield and composition, and economics of the ration in Holstein Friesians cows. Twelve Holstein Friesians cows of almost the same age, and lactation stage were randomly allocated into 4 equal groups i.e. A, B, C, and D. Four experimental rations supplemented with Fibrozyme $^{\circledR} 0 \mathrm{~g}, 5 \mathrm{~g}, 10 \mathrm{~g}$, and $15 \mathrm{~g} / \mathrm{Kg}$ of total mix ration were assigned to these sets correspondingly. The dry matter intake was linearly and significantly $(\mathrm{P}<0.05)$ improved. A significant effect of Fibrozyme ${ }^{\circledR}$ was observed for organic matter digestibility, ether extract digestibility, crude fiber digestibility, nitrogen free extract digestibility, and acid detergent fiber digestibility while the results were statistically non-significant for crude protein digestibility, neutral detergent fiber digestibility, and ash digestibility. Milk yield and composition except fat were significantly $(\mathrm{P}<0.05)$ increased in all Fibrozyme ${ }^{\circledR}$ treated groups. This study concludes that supplementation of Fibrozyme ${ }^{\circledR}$ at the rate of $15 \mathrm{~g} / \mathrm{Kg}$ total mix ration improved the dry matter intake, nutrients digestibility, and milk production and constituents like protein, lactose, and solid not fat. Therefore, treatment of total mix ration with Fibrozyme ${ }^{\circledR}$ was desirably reasonable and profitable.

Keywords: Digestibility; Fibrolytic enzyme; Milk yield; TMR

\section{Introduction}

Pakistan being a tropical country has the major constraints in the form of poor quality and quantity of animal feed resources. The conventional feed for the production of livestock in the country are wheat straw, tops of sugar cane and tree leaves. These feedstuffs despite of their low quality can be better utilized to enhance the profitability of dairy sector in tropical or subtropical countries, especially if their nutritive value is improved by the addition of exogenous enzymes. 
The production capacity of a dairy animal can be enhanced with different approaches like fermentation's manipulation in fore stomach [1]. Therefore, exogenous fibrolytic enzymes addition in feed can be used as a tool to manipulate the fermentation in the rumen [2]. The addition of these enzymes in ruminant rations has been considerably studied in dairy cattle and goats, but variable performance responses have been observed [3-5]. The enzymes related effects in ruminant animals are the result of different pre-feeding and post-feeding mechanisms [6]. The fibrolytic enzymes potentially increase the breakdown of fiber both in vivo and in vitro [7], while the desirable effects of these enzymes seem to be linked with improvements in nutrient digestibility in the rumen [8], the breakdown of cell wall fraction and nutrient digestibility in lactating cows $[8,9]$.

The hot climate forages are low in energy and their cell wall fraction contains lignin, pectin and silica in a high amount limiting the carbohydrate fermentation. To increase the ability of ruminant fore stomach to get essential nutrients from the feed stuffs, is the main objective of the nutritionists. Therefore, this study was planned to see the impact of Fibrozyme $^{\circledR}$ (high xylanases activity from Aspergillus niger and Trichoderma viride fermentation extract) on digestive characteristics of feed stuffs, economics, and production performance of exotic cattle breed Holstein Friesian (HF) under prevailing tropical conditions of the country.

\section{Materials and methods}

\section{Experimental design}

The current research study was conducted at the Dairy Farm of the University of Agriculture Peshawar, Pakistan. Twelve animals of almost the same age, milking stage and body weight were selected and randomly divided into 4 equal groups $(n=3)$. Each experimental animal was treated for ecto and endo parasites before the start of feeding trials. Animals were given a 15 days' adaptation period. Fresh drinking water was available ad libitum throughout the experiment lasted for 25 days. Four experimental rations $1,2,3$, and 4 (Table $1 \&$ 2) were prepared [10], and fed to experimental groups A, B, C, and D respectively.

\section{Feed and fecal analysis}

Representative feed and fecal samples (150g each) were collected in duplicate, properly mixed and thawed for determination of dry matter (DM), crude protein (CP), crude fiber $(\mathrm{CF})$, ether extract (EE), nitrogen free extract (NFE), and ash content according to the standard protocol [11]. Neutral detergent fiber (NDF) determined according to the protocol [12] and acid detergent fiber (ADF) determined according to the previously described procedure [13].

\section{Nutrients digestibility}

Digestibility of DM, organic matter (OM), acid detergent fiber (ADF), neutral detergent fiber (NDF), ether extract (EE), crude fiber $(\mathrm{CF})$, crude protein $(\mathrm{CP})$, nitrogen free extract (NFE) and ash were calculated by the difference between the nutrients consumed and nutrients excreted in faeces by the experimental cows using the equation; Digestibility $(\%)=[(\mathrm{A}-\mathrm{B}) \times(100)] / \mathrm{A}$ Where

$\mathrm{A}=$ Quantity of nutrients consumed by the animal (g/d) i.e. DM, OM, and ADF.

$\mathrm{B}=$ Quantity of the nutrients excreted by the animal in faeces $(\mathrm{g} / \mathrm{d})$

Milk Samples collection and analysis

Milk samples $(100 \mathrm{ml})$ were collected weekly in sterilized plastic bottles from 4 successive milking. Morning and evening milk samples were mixed thoroughly and separately in 1:1 ratio to get two composite milk samples. The samples were kept at $4^{\circ} \mathrm{C}$ until chemical analysis. Representative milk sample of $100 \mathrm{ml}$ was analysed for composition i.e. fat, solids not fat (SNF), lactose, and protein by Lacto scan 
(Milkotronic Ltd, Bulgaria) in Veterinary Research Institute, Peshawar, Pakistan.

\section{Statistical analysis}

Data were statistically analysed with oneway ANOVA and significance among groups was tested with least significant difference test (LSD). The statistical model used is as under:

$Y_{\mathrm{ij}}=\mu+\beta_{\mathrm{j}}+\epsilon_{\mathrm{ij}}$

Whereas; $\mathrm{Y}_{\mathrm{ij}}=$ yield of treatment, $\mu=$ mean of overall treatment, $\beta_{j}=$ Effect of treatment, $\epsilon_{\mathrm{ij}}=$ Random error

\section{Results}

\section{Effect of Fibrozyme ${ }^{\circledR}$ on nutrients intake} and digestibility

The overall dry matter intake (DMI) was significantly $(\mathrm{P}<0.05)$ increased by the supplementation of Fibrozyme ${ }^{\circledR}$. The peak value of DMI in cows was noted on $15 \mathrm{~g} / \mathrm{kg}$, followed by $10 \mathrm{~g} / \mathrm{kg}$ of the total mixed ration (Table 3). Results of the current study showed that organic matter digestibility (OMD), ether extract digestibility (EED), crude fiber digestibility (CFD), nitrogen free extract digestibility (NFED), acid detergent fiber digestibility (ADFD), and neutral detergent fiber digestibility (NDFD) were significantly $(\mathrm{P} \leq 0.05)$ improved by the addition of Fibrozyme ${ }^{\circledR}$ in experimental rations (Table 3). Generally, it was observed that the nutrients digestibility parallel increased with increase in the level of Fibrozyme ${ }^{\circledR}$ in total mixed ration (TMR). On the other hand, results indicated that effect of Fibrozyme ${ }^{\circledR}$ on crude protein digestibility (CPD), and ash digestibility (AD) was not statistically significant (Table 3).

Effect of Fibrozyme ${ }^{\circledR}$ on milk yield and composition

Results indicated that the Fibrozyme ${ }^{\circledR}$ treatments significantly improved the milk yield (MY) in experimental cows in a dose dependent manner (Table 4). Similarly, positive response to Fibrozyme ${ }^{\circledR}$ supplementation was noted in milk composition in terms of protein, lactose, and solids not fat (SNF) percentages. The data showed that fat percentage linearly decreased with increase in Fibrozyme ${ }^{\circledR}$ level in TMR (Table 4).

\section{Economics of the ration}

Results of the experiment showed that Fibrozyme $^{\circledR}$ treatments significantly increased the economic efficiency of the ration. All of the treatments significantly increased economics of the ration as compared to control diet, but there was no significant variation among the Fibrozyme ${ }^{\circledR}$ treatments (Table 4).

Table 1. Formulation of the experimental rations

\begin{tabular}{|c|c|c|c|c|}
\hline & \multicolumn{4}{|c|}{ Ration } \\
\hline Ingredients & $\mathbf{1}(\mathbf{D M}$ Kg) & $\mathbf{2}(\mathbf{D M ~ K g})$ & $\mathbf{3}(\mathbf{D M} \mathbf{~ K g})$ & $\mathbf{4}(\mathbf{D M} \mathbf{~ K g})$ \\
\hline Cotton seed cake & 10.00 & 10.00 & 10.00 & 10.00 \\
\hline Molasses & 4.00 & 4.00 & 4.00 & 4.00 \\
\hline Maize fodder & 60.00 & 60.00 & 60.00 & 60.00 \\
\hline Wheat Bran & 8.00 & 8.00 & 8.00 & 8.00 \\
\hline Rice polish & 10.00 & 10.00 & 9.50 & 9.00 \\
\hline Maize Grind & 7.00 & 7.00 & 7.00 & 7.00 \\
\hline Enzyme & 0.00 & 0.50 & 1.00 & 1.50 \\
\hline Salt & 0.50 & 0.25 & 0.25 & 0.25 \\
\hline Mineral Mix & 0.50 & 0.25 & 0.25 & $0 . .25$ \\
\hline Total & $\mathbf{1 0 0 . 0 0}$ & $\mathbf{1 0 0 . 0 0}$ & $\mathbf{1 0 0 . 0 0}$ & $\mathbf{1 0 0 . 0 0}$ \\
\hline
\end{tabular}


Table 2. Chemical composition of experimental rations

\begin{tabular}{|c|c|c|c|}
\hline Ingredients & DM\% & TDN\% & CP\% \\
\hline Cotton seed cake & 99 & 75 & 24 \\
\hline Molasses & 76 & 75 & 5 \\
\hline Maize fodder & 40 & 67 & 17 \\
\hline Wheat Bran & 89 & 70 & 10 \\
\hline Rice Polish & 88 & & 14 \\
\hline Maize Grind & 89 & 88 & 0 \\
\hline Fibrozyme $^{\circledR}$ & 99 & 0 & 0 \\
\hline Salt (NaCl) & 96 & 0 & 0 \\
\hline Mineral Mix & 99 & 0 & \\
\hline
\end{tabular}

*Means in each row with different superscript are significantly different at $\mathrm{P}<0.05$

$\mathbf{1}=$ Basal diet + Fibrozyme $^{\circledR}(0 \mathrm{~g} / \mathrm{Kg}), 2$ = Basal diet + Fibrozyme $^{\circledR}(5 \mathrm{~g} / \mathrm{Kg}), \mathbf{3}=$ Basal diet + Fibrozyme ${ }^{\circledR}(10 \mathrm{~g} / \mathrm{Kg})$, $\mathbf{4}=$ Basal diet + Fibrozyme $^{\circledR}(15 \mathrm{~g} / \mathrm{Kg}), \mathrm{DM}=$ dry matter, $\mathrm{TDN}=$ total digestible nutrients

Table 3. Effect of Fibrozyme ${ }^{\circledR}$ on DMI and nutrients digestibility (Mean \pm S.E) in Holstein Friesian cows

\begin{tabular}{|c|c|c|c|c|}
\hline \multirow{2}{*}{ Parameters } & \multicolumn{4}{|c|}{ Ration } \\
\cline { 2 - 5 } & $\mathbf{1}(\mathbf{0 g} / \mathbf{K g})$ & $\mathbf{2}(\mathbf{5 g} / \mathbf{k g})$ & $\mathbf{3}(\mathbf{1 0 g} / \mathbf{K g})$ & $\mathbf{4}(\mathbf{1 5 g} / \mathbf{K g})$ \\
\hline DMI (Kg/day) & $13.56^{\mathrm{b}} \pm 0.49$ & $14.33^{\mathrm{a}} \pm 0.49$ & $16.06^{\mathrm{a}} \pm 0.49$ & $16.20^{\mathrm{a}} \pm 0.49$ \\
\hline CPD (\%) & $69.99^{\mathrm{a}} \pm 0.64$ & $69.79^{\mathrm{a}} \pm 0.64$ & $68.71^{\mathrm{a}} \pm 0.64$ & $69.79^{\mathrm{a}} \pm 0.64$ \\
\hline OMD (\%) & $65.48^{\mathrm{b}} \pm 0.96$ & $66.15^{\mathrm{b}} \pm 0.96$ & $68.35^{\mathrm{a}} \pm 0.96$ & $68.70^{\mathrm{a}} \pm 0.96$ \\
\hline EED (\%) & $69.64^{\mathrm{c}} \pm 0.47$ & $70.08^{\mathrm{b}} \pm 0.47$ & $71.08^{\mathrm{ab}} \pm 0.47$ & $71.47^{\mathrm{a}} \pm 0.47$ \\
\hline CFD (\%) & $87.31^{\mathrm{c}} \pm 0.64$ & $88.87^{\mathrm{b}} \pm 0.64$ & $90.04^{\mathrm{ab}} \pm 0.64$ & $91.22^{\mathrm{a}} \pm 0.64$ \\
\hline AD (\%) & $63.42^{\mathrm{a}} \pm 1.71$ & $64.06^{\mathrm{a}} \pm 1.71$ & $64.80^{\mathrm{a}} \pm 1.70$ & $65.70^{\mathrm{a}} \pm 1.71$ \\
\hline NFED (\%) & $53.30^{\mathrm{a}} \pm 2.09$ & $53.95^{\mathrm{a}} \pm 2.09$ & $58.18^{\mathrm{b}} \pm 2.09$ & $58.86^{\mathrm{b}} \pm 2.09$ \\
\hline NDFD (\%) & $64.02^{\mathrm{b}} \pm 1.13$ & $65.46^{\mathrm{ab}} \pm 1.13$ & $65.46^{\mathrm{ab}} \pm 1.13$ & $67.75^{\mathrm{a}} \pm 1.13$ \\
\hline ADFD (\%) & $52.67^{\mathrm{c}} \pm 0.55$ & $54.02^{\mathrm{b}} \pm 0.55$ & $54.08^{\mathrm{b}} \pm 0.55$ & $55.31^{\mathrm{a}} \pm 0.55$ \\
\hline
\end{tabular}

*Means in each row with different superscript are significantly different at $\mathrm{P}<0.05$

$\mathbf{1}=$ Basal diet + Fibrozyme $^{\circledR}(0 \mathrm{~g} / \mathrm{Kg}), \mathbf{2}=$ Basal diet + Fibrozyme $^{\circledR}(5 \mathrm{~g} / \mathrm{Kg}), \mathbf{3}=$ Basal diet + fibrozyme $(10 \mathrm{~g} / \mathrm{Kg}), \mathbf{4}=$ Basal diet + Fibrozyme ${ }^{\circledR}(15 \mathrm{~g} / \mathrm{Kg})$

Table 4. Effect of Fibrozyme ${ }^{\circledR}$ on milk yield (L/day) and composition (\%), and economics of the ration (Rupees) in lactating cows

\begin{tabular}{|c|c|c|c|c|}
\hline \multirow{2}{*}{ Parameters } & \multicolumn{4}{|c|}{ Ration } \\
\cline { 2 - 5 } & $\mathbf{1}(\mathbf{0 g} / \mathbf{K g})$ & $\mathbf{2}(\mathbf{5 g} / \mathbf{K g})$ & $\mathbf{3}(\mathbf{1 0 g} / \mathbf{K g})$ & $\mathbf{4}(\mathbf{1 5 g} / \mathbf{K g})$ \\
\hline Milk yield & $15.68^{\mathrm{b}} \pm 1.42$ & $19.56^{\mathrm{a}} \pm 1.42$ & $20.95^{\mathrm{a}} \pm 1.42$ & $21.27^{\mathrm{a}} \pm 1.42$ \\
\hline Protein & $2.88^{\mathrm{c}} \pm 0.024$ & $2.90^{\mathrm{bc}} \pm 0.024$ & $2.97^{\mathrm{a}} \pm 0.024$ & $3.10^{\mathrm{a}} \pm 0.024$ \\
\hline Fat & $4.44^{\mathrm{a}} \pm 0.048$ & $3.32^{\mathrm{b}} \pm 0.048$ & $3.22^{\mathrm{b}} \pm 0.048$ & $2.67^{\mathrm{c}} \pm 0.048$ \\
\hline Lactose & $3.82^{\mathrm{c}} \pm 0.057$ & $4.12^{\mathrm{b}} \pm 0.057$ & $4.86^{\mathrm{a}} \pm 0.057$ & $4.91^{\mathrm{a}} \pm 0.057$ \\
\hline SNF & $7.77^{\mathrm{b}} \pm 0.098$ & $8.02^{\mathrm{ab}} \pm 0.098$ & $8.10^{\mathrm{a}} \pm 0.098$ & $8.10^{\mathrm{a}} \pm 0.098$ \\
\hline Economics & $941^{\mathrm{b}} \pm 85.59$ & $1207^{\mathrm{a}} \pm 85.59$ & $1292^{\mathrm{a}} \pm 85.59$ & $1294^{\mathrm{a}} \pm 85.59$ \\
\hline
\end{tabular}

*Means in each row with different superscript are significantly different at $\mathrm{P}<0.05$

$\mathbf{1}=$ Basal diet + Fibrozyme $^{\circledR}(0 \mathrm{~g} / \mathrm{Kg}), 2=$ Basal diet + Fibrozyme $^{\circledR}(5 \mathrm{~g} / \mathrm{Kg}), \mathbf{3}=$ Basal diet + Fibrozyme ${ }^{\circledR}(10 \mathrm{~g} / \mathrm{Kg})$, $\mathbf{4}=$ Basal diet + Fibrozyme $^{\circledR}(15 \mathrm{~g} / \mathrm{Kg})$ 


\section{Discussion}

In the present study, DMI was significantly $(\mathrm{P}<0.05)$ increased with the supplementation of Fibrozyme $^{\circledR}$ at the rate of 10 and $15 \mathrm{~g} / \mathrm{kg}$ of TMR. These outcomes are consistent with the findings reported in earlier studies [14] in which different levels of fibrolytic enzyme were fed to dairy cattle, and significantly enhanced DMI was noted. Associated with these results, Ware and Zinn [15] added fibrolytic enzyme to the TMR of steers and found the positive impact on DMI of experimental animals. Furthermore, Szasz et al. [16] incorporated fibrolytic enzyme to yearling heifer's ration, and they found higher DMI compared with the ration without the enzyme addition. Previous studies reported increased DMI when dairy cattle were fed with fibrolytic enzymes [17]. Several other researchers noted increased DMI of dairy cattle when fibrolytic enzymes were added to TMR or concentrate ration $[18,19]$. This improvement in DMI might be credited to the capability of exogenous enzymes (Fibrozyme ${ }^{\circledR}$ ) to activate the production of fibrolytic, and lactate consuming bacteria in the cattle rumen, which can increase the rumen $\mathrm{pH}$, and fiber digestibility, ultimately increased DMI. Ahn et al. [20] reported that fibrolytic enzyme supplementation to dairy cows at the level of 0.05 and $0.1 \%$ of TMR did not increase DMI and no difference was recorded between cows fed with enzymes treated or untreated diet.

Increased NDFD by the addition of Fibrozyme ${ }^{\circledR}$ was observed in experimental cows. These findings are in agreement with the outcomes reported in previous studies $[9,22,23]$ that supplementation of fibrolytic enzymes results in improved NDFD in dairy cattle. This increase in digestibility of NDF may be attributed to the fact that NDF content of plants cell wall increase the ruminal $\mathrm{pH}$ (less fermentation), and activity of cellulolytic bacteria. Additional, in earlier studies [24], rises in the digestibility of NDF without influencing DMI by supplementation of fibrolytic enzymes into cattle ration have been reported. In present experiment, improved ADFD was observed with supplementation of Fibrozyme ${ }^{\circledR}$ in the ration. Earlier scientists have already reported similar results that fibrolytic enzyme treatment of ration enhance the degradation of cell wall of corn forages [25]. Results of the study showed higher CPD for Fibrozyme ${ }^{\circledR}$ supplemented rations. According to McAllister et al. [21], fibrolytic enzymes supplementation in rations stimulate proteolytic bacteria thereby increasing fiber bounded proteins degradation. Table (3) showed higher OMD in Fibrozyme ${ }^{\circledR}$ treated cows. Significant increase in OMD might be due to the increased attachment of enzyme to the content of the plant cell resulting in enhanced degradation.

In current study, the highest level of Fibrozyme ${ }^{\circledR}$ $(15 \mathrm{~g} / \mathrm{kg}$ TMR $)$ significantly $(\mathrm{p} \leq 0.05)$ increased milk production in experimental cows. These findings are closely related to the outcomes of previous studies $[5,20]$, that the supplementation of fibrolytic enzyme in diet improved milk yield in dairy cows. Similarly in Egypt, Mansour [26] compared MY for two groups of dairy cows fed with and without fibrolytic enzyme respectively. He observed higher MY for enzyme treated group compared with enzyme untreated group. These increases in MY with supplementation of fibrolytic enzyme may be attributed to the increase in DMI and as showed by several previous studies with fibrolytic enzyme, that may be due to better utilization and availability of nutrients (crude fiber) in gastrointestinal tract of animals, resulting in increased net energy gain. Supplementation of Fibrozyme ${ }^{\circledR}$ to cows had no statistically significant effect on milk protein content. Associated with these findings, Reddish and Kung [27] observed no significant effect for fibrolytic enzymes supplementation on milk composition of dairy cow. On the other hand, Gado et al. [28] reported that milk protein yield for Brown Swiss cows was statistically increased for cows fed on $\mathrm{ZADO}^{\circledR}$ (including $7.1 \mathrm{unit} / \mathrm{g}$ of cellulase, $2.3 \mathrm{unit} / \mathrm{g}$ of xylanase, $61.5 \mathrm{unit} / \mathrm{g}$ of $\alpha$ - amylase and $29.2 \mathrm{unit} / \mathrm{g}$ of proteases) added diet compared with cows fed control diet. Several previous studies reported that milk composition i.e. fat, lactose, SNF, and protein of dairy cows were not affected by supplementation of fibrolytic enzyme in the diet $[29,30]$.

Milk lactose content was positively increased in the study by the supplementation of fibrolytic enzyme in the milk of dairy cows. These findings are in close agreement with the results quoted by earlier researchers [5, 17, 23] who reported positive impact on milk lactose content with fibrolytic enzyme supplementation in the diet of dairy cows. Improvement in lactose content of 
milk could be due to increase concentration of glucose and glucose is precursors for the synthesis of milk lactose in mammary gland. Results of the present study revealed that solid not fat (SNF) content of cow's milk increased with Fibrozyme ${ }^{\circledR}$ supplementation in the diet. The outcomes are supported by earlier study in which significant effect of fibrolytic enzyme was noted on milk SNF content of dairy buffaloes [14]. In current experiment, the supplementation of Fibrozyme $^{\circledR}$ to TMR for lactating cattle significantly $(\mathrm{P}<0.05)$ raised $\mathrm{MY}$ and composition. Therefore, the supplemented ration for experimental dairy cows was highly economical.

\section{Conclusion}

In conclusion, under tropical environment supplementation of dairy cattle ration with Fibrozyme ${ }^{\circledR}$ at the rate of $10 \mathrm{~g} / \mathrm{Kg}$ TMR, enhanced the DMI as well as plants cell wall digestibility. Its supplementation also significantly increased MY and composition i.e. milk SNF, and lactose content, so that the ration supplemented with fibrozyme was significantly economical.

\section{Authors' contributions}

Conceived and designed the experiments: HS Sidique, MT Khan, \& M Mobashar, Performed the experiments: HS Sidique, Analysed the data: MT Khan, Contributed materials/ analysis/ tools: I Ahmad, S Mehmood, Wrote the paper: H Ullah \& MT Khan.

\section{References}

1. Salem AZM, Alsersy H, Camacho LM, ElAdawy MM, Elghandour MMY, Kholif AE, Rivero N, Alonso MU \& Zaragoza A (2015). Feed intake, nutrient digestibility, nitrogen utilization, and ruminal fermentation activities in sheep fed Atriplex halimus ensiled with three developed enzyme cocktails. Czech J Anim Sci, 60: 185-194.

2. Rojo R, Kholif AE, Salem AZM, Elghandour MMY, Odongo NE, de Oca RM, Rivero N \& Alonso MU (2015). Influence of cellulase addition to dairy goat diets on digestion and fermentation, milk production and fatty acid content. The J Agri Sci, 153: 1514-1523.

3. Beauchemin KA, Rode LM, Maekawa M, Morgavi DP \& Kampen R (2000). Evaluation of a nonstarch polysaccharidase feed enzyme in dairy cow diets. J Dairy Sci 83: 543-553.

4. González E, Caja G, Albanell E, Flores C, Casals R \& Such X (2008). Lactational effects of adding a fibrolytic enzyme complex to the concentrate of lactating dairy goats. J Anim Feed Sci 17: 344-351.

5. Kung, Jr. L, Treacher RJ, Nauman GA, Smagala AM, Endres KM \& Cohen, MA (2000). The effect of treating forages with fibrolytic enzymes on its nutritive value and lactation performance of dairy cows. J Dairy Sci 83: 115-122.

6. Colombatto D, Mould FL, Bhat MK \& Owen E (2003). Use of fibrolytic enzymes to improve the nutritive value of ruminants' diets. A biochemical and in vitro rumen degradation assessment. Anim Feed Sci Technol 107: 201-209.

7. Yang WZ, Beauchemin KA \& Rode LM (1999). Effects of an enzyme feed additive on extent of digestion and milk production of lactating dairy cows. J Dairy Sci 82: 391403.

8. Feng P, Hunt CW, Pritchard GT \& Julien WE (1996). Effect of enzyme preparations on in situ and in vitro degradation and in vivo digestive characteristics of mature cool-season grass forage in beef steers. $J$ Anim Sci 74: 1349-1357.

9. Lewis GE, Hunt CW, Sanchez WK, Treacher R, Pritchard, GT \& Feng P (1996). Effect of direct-fed fibrolytic enzymes on the digestive characteristics of a foragebased diet fed to beef steers. J Anim Sci 74: 3020-3028.

10. NRC (2007). Nutrient Requirements of Large Ruminants. National Academy Press, Washington, DC.

11. Association of Official Analytical Chemists (1990). Official methods of analysis of the Association of Official Analytical Chemists (Vol. 1). The Association.

12. Goering HK \& Van Soest PJ (1970). Fiber analysis (apparatus, reagents, procedures, and some applications) Agric. Handbook 379. ARS. USDA. Washington. DC.

13. Van Soest PJ, Robertson JB \& Lewis BA (1991). Methods for dietry fiber, neutral detergent fiber and non -starch 
polysaccharides in relation to animal nutrition. J Dairy Sci 74: 3583-3597.

14. Gaafar HA, Raouf EE \& Reidy KFA (2010). Effect of fibrolytic enzyme supplementation and fiber content of total mixed ration on productive performance of lactating buffaloes. Slovak J Anim Sci 43: 147-153.

15. Ware RA \& Zinn R A (2005). Influence of Maceration and fibrolytic enzyme on the feeding value of rice straw. J Anim Vet Adv 4: 387-392.

16. Szasz JL, Mc Calmant TM, Hunt CW, Grove AV \& Kennington LR (2002). Effect of a fibrolytic enzyme preparation on intake and digestibility of bluegrass seed straw fed to beef cattle. In Proc-American Soc of Animal Sci West Sec 53: 313-316.

17. Lewis GE, Sanchez WK, Hunt CW, Guy MA, Pritchard GT, Swanson BI \& Treacher Rj (1999). Effect of Direct Fed Fibrolytic Enzymes on Lactational Performance of Dairy Cows. J Dairy Sci 82: 611-617.

18. Yang, WZ, Beauchemin KA \& Rode LM (2000). A Comparison of Methods of Adding Fibrolytic Enzymes. J Dairy Sci 83: 2512-2520.

19. Bowman GR, Beauchemin KA \& Shelord JA (2002). The Proportion of the Diet to Which Fibrolytic Enzymes is Added Affects Nutrient Digestion by Lactating Cows. $J$ Dairy Sci 85: 3420-3429.

20. Ahn JH, Kim YJ \& Kim HJ (2003). Effects of fibrolytic enzyme addition on ruminal fermentation, milk yield and milk composition of dairy cows. J Anim Sci Technol 45: 131-142.

21. McAllister TA, Oosting S, Popp JD, Mir Z, Yanke LJ, Hristov AN, Treacher RJ \& Cheng KJ (1999). Effect of exogenous enzymes on digestibility of barley silage and growth performance of feedlot cattle. Canadian J Anim Sci 79: 353-360.

22. Krause M, Beauchemin KA, Rode LM, Farr BI \& Norgaard P (1998). Fibrolytic enzyme treatment of barley grain and source of forage in high-grain diets fed to growing cattle. J Anim Sci 76: 2912-2920.

23. Rode LM, Yang WZ \& Beauchemin KA (1999). Fibrolytic enzyme supplemented for dairy cows in early lactation. J Dairy Sci 82: 2121-2126.

24. Beauchemin KA, Yang WZ \& Rode LM (19990. Effect of grain source and enzyme additive on site and extent of nutrient digestion in dairy cows. J Dairy Sci 82: 378390.

25. Pinos RJM, González SS, Mendoza GD, Bárcena R, Cobos MA, Hernández A \& Ortega M (2002). Effect of exogenous fibrolytic enzyme on ruminal fermentation and digestibility of alfalfa and rye-grass hay fed to lamb. J Anim Sci 80: 3016-3020.

26. Mansour MA (2009). Alleviation of stress for promoting physiological and productive performance of Friesian cattle. Master thesis. Fac. Agric., Cairo Univ. Giza, Egypt.

27. Reddish MA \& Kung Jr, L (2007). The effect of feeding a dry enzyme mixture with fibrolytic activity on the performance of lactating cows and digestibility of a diet for sheep. J Dairy Sci 90: 4724-4729.

28. Gado HM, Salem AZM, Robinson PH \& Hassan M (2009). Influence of exogenous enzymes on nutrient digestibility, extent of ruminal fermentation as well as milk production and composition in dairy cows. Anim Feed Sci Technol 145: 36-46.

29. Knowlton KF, Mckinney JM \& Cobb EA (2002). Effect of a Direct-Fed Fibrolytic Enzyme Formulation on Nutrient Intake, Partitioning, and Excretion in Early and Late Lactation Holstein Cows. J Dairy Sci, 82: 611-617.

30. Elwakeel EA, Tigemeyer EC, Johnson BJ, Armendariz CK \& Shirley JE (2007). Fibrolytic enzyme to increase the nutritive value of dairy feedstuffs. J Dairy Sci 90: 5226-5236. 